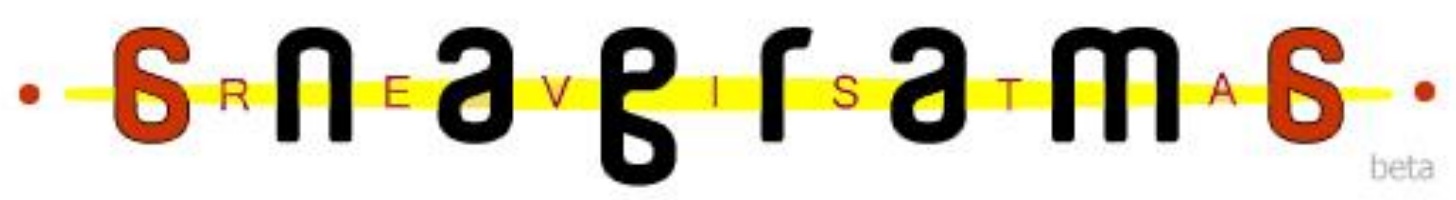 JORRPLISTMO DE SOLUÇÃO E A PRODUÇÃO DE UT JORNALISTO
} ERGAJADOR ${ }^{1}$

Isadora Dezorzi Gerevini

\section{Resumo}

O presente artigo teve como objetivo investigar se o programa Cidades e Soluções, veiculado pela GloboNews, enquadra-se na categoria de Jornalismo de Solução (JS), a partir dos conceitos propostos pela Solutions Journalism Network (2020). O artigo também se apoiou nas pesquisas de Wenzel, Gerson e Moreno (2016) sobre o tema. Através de pesquisa bibliográfica, buscou as origens do JS em correntes antigas, como o Jornalismo para a Paz, descrita por Johan Galtung (1970), e o Jornalismo Cívico (1980), para entender as semelhanças e diferenciações. Para a análise, foram escolhidas quatro edições de Cidades e Soluções, sendo que a metodologia consistiu em uma análise de conteúdo. A partir dos resultados da análise, foi possível concluir que Cidades e Soluções se enquadra na categoria de JS, já que, nas edições avaliadas, constam as características delimitadas pela Solutions Journalism Network.

Palauras-chaue: Cidades e Soluções; Jornalismo de Solução; Solutions Journalism Network.

\section{IกTRODUÇि̃O}

Um jornalismo que engaje, comunique para todos e apresente soluções para problemas recorrentes se faz cada vez mais necessário. Diante desse contexto, o presente artigo teve como objetivo analisar o programa Cidades e Soluções, veiculado pela GloboNews, usado como amostragem, à luz do conceito de Jornalismo de Soluções (JS)

\footnotetext{
1 Artigo produzido como requisito para a conclusão do Curso de Jornalismo, pela Faculdade de Artes e Comunicação da Universidade de Passo Fundo.

${ }^{2}$ Formada em Jornalismo pela Universidade de Passo Fundo. E-mail: 158149@upf.br.
} 
proposto pela Solutions Journalism Network (2020). A partir das características e exemplos apresentados, a pesquisa buscou concluir se o programa se enquadra no conceito do JS e entender de que forma essa categoria pode ser um agente de mudança no jornalismo atual.

Para isso, foram utilizadas como base teórica, as definições de Jornalismo de Solução fornecidas pela Solutions Journalism Network (2020). Além disso, o estudo apoiou-se nas pesquisas de Wenzel, Gerson e Moreno (2016). Porém, o conceito de Jornalismo de Solução é recente e teorias completas ainda se fazem necessárias. Como estudo complementar, o artigo abordou o Jornalismo para Paz, descrito, inicialmente, por Johan Galtung (1970), e o Jornalismo Cívico, surgido nos anos 1980 nos Estados Unidos, apresentados como antecessores do Jornalismo de Solução. Os conceitos foram estudados através de uma pesquisa bibliográfica para tentar compreender quais características os tornam semelhantes e o que os diferencia. Para a análise, foram selecionadas quatro edições do programa Cidades e Soluções, voltado a apresentar e debater experiências que impactaram positivamente a vida das pessoas nas cidades.

\section{UMTA SOLUÇÃO AO JORNALISTIO ATUAL}

Que o jornalismo tem enfrentado grandes desafios, não é novidade. A forma de produção e entrega de notícias modificaram-se com o tempo e com o desenvolvimento de novas tecnologias, os prazos de produção ficaram ainda mais curtos e as redações diminuíram. Esse novo cenário passou a ser visto como uma crise que o jornalismo estaria atravessando: "Reina um sentimento de indefinição, e a crise é crise de valores, crise de identidade, crise financeira" (PEREIRA; ADGHIRNI, 2011, p. 40 apud CARRARO, 2016).

A queda das receitas nos veículos acabou levando à demissão de profissionais e à diminuição de investimentos para a produção de reportagens com aprofundamento e investigação. "Essa crise de identidade soma-se a uma constante e gradual perda de credibilidade das mídias convencionais que, por assumir uma lógica mercantil acelerada, tem proporcionado o esvaziamento de seu poder investigativo" (SOUZA, 2018, s./p).

Como alternativa ao jornalismo que estava sendo produzido, surge o Jornalismo de Solução, o qual objetiva relatar uma informação, mostrando onde e como as pessoas estão achando melhores soluções para problemas, oferecendo uma visão mais abrangente e representativa do mundo. 
Essa categoria foi criada para responder ao afastamento dos leitores do jornalismo ao identificar no viés negativista da cultura jornalística, centrado na cobertura de problemas, uma das causas para a crise. Essa visão pessimista não produz apenas uma representação distorcida da realidade, como também gera um sentimento de descrença generalizada e apatia política cuja consequência é o desligamento do público do jornalismo e da democracia (DE SOUZA, 2017, p. 10).

Dessa forma, o Jornalismo de Solução visa desencadear reflexões e ação do leitor, que ao perceber que certo problema foi resolvido em determinado lugar, se sentirá empoderado para agir também. Segundo Wenzel, Gerson e Moreno (2016), as histórias mais poderosas do JS utilizam o rigor das reportagens investigativas para explorar os porquês dos males sociais e examinar os esforços para resolvê-los. Sendo assim, não abordam apenas um problema seguido de breves reflexões. O JS explora e aprofunda, examina de forma crítica problemas enfrentados pela sociedade e dá luz para soluções que tiveram êxito em diferentes localidades. Para disseminar a cultura do JS em todo o mundo e apresentar características que o conceituem de maneira mais clara, surgiu em 2013, a Solutions Journalism Network, que, segundo a própria organização, "visa treinar e conectar jornalistas para cobrir o que está em falta hoje: como as pessoas estão respondendo a problemas" (SOLUTION JOURNALISM NETWORK, 2020, s./p.).

De acordo com a Solutions Journalism Network (2020), Jornalismo de Solução é uma resposta rigorosa a problemas sociais, ou seja, busca mostrar como um problema social teve solução ou foi amenizado, de forma explicada e abrangendo todo o processo e desdobramentos possíveis, para que a solução encontrada possa motivar ou ser implementada em demais locais.

Além das características mais abrangentes, a organização elenca alguns pontos que caracterizam o Jornalismo de Solução como:

Pode ser orientado pelo personagem, mas se concentra em profundidade na resposta a um problema e como esta resposta funciona de forma detalhada; concentra-se na eficácia e não em boas intenções, apresentando evidências de resultados; discute as limitações da abordagem; busca fornecer insights que outras pessoas possam utilizar ou tomar como exemplo em diferentes lugares (SOLUTIONS JOURNALISM NETWORK, 2020, s./p).

O JS é um termo relativamente novo na imprensa brasileira, tendo surgido, inicialmente, nos Estados Unidos. Segundo Loose (2019), pesquisadores da área dizem que 
pelas características que apresenta tem origem no Jornalismo Cívico ou até mesmo no Jornalismo para Paz. Porém, uma teoria completa que o descreva ainda é escassa, mas muito se relaciona com as duas categorias citadas anteriormente, que nasceram através de movimentos da sociedade e serão explicadas a seguir.

\section{JORחALISTIO PARA A PAZ E JORחALISTIO CÍUICO: INSPIRAÇÃO PARA OJORIALISTIO DE} SOLUÇก̃O

O Jornalismo para a Paz, considerado um dos antecessores do Jornalismo de Solução, surgiu nos anos 1970. De acordo com Loose (2019), o sociólogo Johan Galtung é considerado a referência desse movimento, que o criou pensando na oposição do jornalismo de guerra, orientado apenas para o conflito e suas consequências visíveis. Segundo Cardoso (2013), a base para o conceito faz parte de um movimento de reforma do jornalismo internacional, com a publicação de um artigo "The Structure of Foreign News".

$\mathrm{Na}$ época, os pesquisadores colocavam em questão como os eventos se transformavam em notícias e, para isso, trabalharam com o fato de a mesma seguir linhas de edições que partiam de convenções jornalísticas engessadas, enquanto o próprio acontecimento exigia flexibilidade e perspectivas mais amplas para ser compreendido (CARDOSO, 2013, p. 80).

Para McGoldrick e Lynch (apud Salhani e Cabral 2017), o Jornalismo para a Paz traça novas linhas de conexão entre os jornalistas, fontes e consequências utilizando a análise e transformação de conflitos para chegar a um equilíbrio, igualdade e aumentar o rigor das coberturas jornalísticas. Segundo Cardoso (2013), como técnica incentiva a ordem social, porque inclui o discurso do conflito ou da diferença social como estratégia de paz ou reflexão, tendo como desafio tirar o público da apatia e promover engajamento.

Os autores Cabral e Salhani (2017), definem o jornalismo orientado para a paz através das seguintes características propostas, anteriormente, por Johan Galtung:

Orientado para a paz/conflito: explora a formação de conflitos, partes, objetivos e problemas múltiplos, todas as partes ganham; Espaço e tempo abertos: causas e consequências em qualquer lugar, inclusive na história e na cultura, apresenta os conflitos com transparência; Dá voz a todas as partes, com empatia e entendimento; Vê conflito e guerra como problemas e foca na criatividade; Humaniza todas as partes, especialmente quando há armamentos; É proativo: busca a prevenção antes que a violência e guerra ocorram; Foca nos efeitos invisíveis da violência: traumas, danos à estrutura e à cultura (CABRAL; SALHANI, 2017, p. 4). 
Assim como o Jornalismo para Paz, outra vertente nasceu da vontade de engajar o público. O Jornalismo Cívico começou a ser debatido pela primeira vez no fim da década de 1980, nos Estados Unidos. “A iniciativa nasceu como uma reação de alguns periódicos estadunidenses à sucessiva queda nas vendas e ao descrédito que enfrentavam, constatado por meio de pesquisas" (PENA, 2005 apud LIMA; MOTA, 2014). Segundo Lima e Mota (2014), o movimento buscava colocar os cidadãos no centro, responder a seus anseios e necessidades reafirmando a democracia e incentivando a participação política da população, já que nos Estados Unidos o voto é facultativo.

Os primeiros adeptos ao Jornalismo Cívico e defensores do movimento, partiram de dois pressupostos:

\begin{abstract}
1) a situação atual em que se encontra o jornalismo é desfavorável porque o interesse das pessoas na vida pública diminuiu de maneira considerável; 2) diante desse cenário, ao jornalismo e seus agentes não cabe um posicionamento vitimizado, tendo em vista que também são responsáveis pelo descrédito da população na democracia e na vida pública, seja por um recorrente uso do sensacionalismo, pela ênfase no entretenimento ou pela veiculação de informações que não contribuem para um processo reflexivo dos leitores/espectadores/receptores (LIMA; MOTA, 2014, p. 31).
\end{abstract}

A partir dos conceitos e características do Jornalismo para Paz e do Jornalismo Cívico, é possível constatar que o Jornalismo de Solução se utiliza de alguns pontos para formular sua própria construção. Assim como os antecessores, o Jornalismo de Solução visa contextualizar um fato e uma maior aproximação com o público, da mesma forma que é centrado nos sujeitos e busca envolvê-los no debate público. Para Loose (2019), todos reivindicam por um outro olhar e enquadramento, que valoriza a participação do cidadão e entende o jornalista como um ator que pode intervir na sociedade.

Apesar de ambos partirem do desejo de aumentar o engajamento com o público, inseri-los no debate e apresentar novas faces da notícia, é possível constatar algumas diferenças entre eles. O Jornalismo para Paz nasceu essencialmente da percepção de que o jornalismo estava abarrotado de notícias negativas. Para Cabral e Salhani (2017, p. 4), "estuda-se o jornalismo e sua relação com a paz por este estar amplamente permeado pela violência." Assim, o maior objetivo do Jornalismo para Paz foi contrapor-se ao jornalismo de guerra. Já no movimento do Jornalismo Cívico, a diferença que podemos constatar é que "nos EUA, o jornalismo cívico sempre esteve associado a uma função de formação do eleitor e o estímulo ao voto consciente em candidatos que possam resolver os problemas 
das pessoas" (SILVA, 2012, p. 56). Apesar do Jornalismo de Solução objetivar a conscientização em todos os âmbitos e, consequentemente, na vida política, isso não aparece como uma característica central, pois, segundo Souza (2017, p. 12), “objetiva munir os cidadãos com conhecimentos para promover um debate público instruído e para habilitar os indivíduos a encontrarem soluções para os problemas de suas comunidades." A partir dos autores, pode-se destacar que o foco principal do Jornalismo de Solução é, portanto, engajar as pessoas a buscarem soluções para problemas locais através dos exemplos noticiados de soluções que deram certo em diferentes partes do mundo.

\section{METODOLOGIA}

O presente artigo teve como objetivo analisar o programa Cidades e Soluções, veiculado pela GloboNews, à luz do conceito de Jornalismo de Soluções proposto pela Solutions Journalism Network (2020). Como objeto de análise foram escolhidas quatro reportagens do programa Cidades e Soluções, uma produção brasileira transmitida pela GloboNews desde 2007, e apresentada pelo jornalista André Trigueiro, e que consiste numa série de reportagens que trazem soluções e exemplos que transformaram positivamente a vida das pessoas.

Para a pesquisa, foram selecionadas as seguintes edições: "Novo Coronavírus: cuidados no cotidiano", veiculada em 22 de março de 2020; "Folia Sustentável”, veiculada em 21 de fevereiro de 2020; "Plantadores de árvores: conheça iniciativas que ajudam o planeta", veiculada em 23 de setembro de 2019; "Brasil trata menos da metade do esgoto que gera”, veiculada em 30 de abril de 2018. A escolha privilegiou os conteúdos que não dependiam de assinatura no canal, dessa forma, prezou-se por avaliar apenas as que estão disponíveis para todos, que poderão utilizar as informações e exemplos fornecidos.

A metodologia utilizada foi a análise de conteúdo jornalístico,

[...] método de pesquisa que recolhe e analisa textos, sons, símbolos e imagens impressas, gravadas ou veiculadas em forma eletrônica ou digital encontrados na mídia a partir de uma amostra aleatória ou não dos objetos estudados com o objetivo de fazer inferências sobre seus conteúdos e formatos enquadrando-os em categorias previamente testadas, mutuamente exclusivas e passíveis de replicação (HERSCOVITZ, 2010, p. 126).

Por meio da análise de conteúdo, é possível realizar uma análise quantitativa e qualitativa, onde ao mesmo tempo que apresenta números concretos sobre determinadas 
incidências, também possibilita vislumbrar o conteúdo de forma clara. Como esclarece Herscovitz (2010, p.123), essa metodologia pode ser utilizada para detectar tendências e modelos na análise de critérios de noticiabilidade, enquadramentos e agendamentos, ao passo que serve para descrever e classificar produtos, gêneros e formatos jornalísticos.

As categorias de análise que embasam o estudo foram extraídas da fundamentação teórica e são: Profundidade da resposta: como se dá o desenvolvimento da solução e como funciona de forma aplicada; Como a resposta funciona de forma detalhada: quais as etapas, processos e funções necessárias para que a resposta funcione; Eficácia e evidência dos resultados: quais foram os resultados obtidos através da solução aplicada; Limitações da abordagem: até onde a solução funciona e quais limitações ainda precisam ser superadas; Fornece insights: servir como inspiração, gerar novas ideias e aplicações e fornecer uma compreensão acerca de um problema e uma possível solução. Todas as características são propostas pela Solutions Journalism Network (2020) e descritas no site da organização.

\section{CIDADES E SOLUÇÔES: A CRIATIUIDADE ETT AÇÃO PARA SOLUCIONAR PROBLEMTAS}

Como descrito na metodologia, quatro reportagens foram utilizadas como corpus para a realização da seguinte pesquisa. A análise foi guiada pelas características propostas pela Solutions Journalism Network, a fim de concluir se Cidades e Soluções é, de fato, um programa de Jornalismo de Solução e quantas destas características são perceptíveis nas reportagens analisadas. Para a análise qualitativa foram feitas inferências, ou seja, trechos que condizem com as características foram descritos a fim de demonstrar em que o conceito está presente. Para a análise quantitativa, as características presentes em cada reportagem foram assinaladas com o "X", no Quadro 1, a seguir: 
Quadro 1 - Características do JS presentes nas reportagens

\begin{tabular}{|c|c|c|c|c|c|}
\hline \multirow{2}{*}{ REPORTAGENS } & \multicolumn{5}{|c|}{ CARACTERÍSTICAS } \\
\cline { 2 - 6 } & $\begin{array}{c}\text { Profundidad } \\
\text { e da resposta }\end{array}$ & $\begin{array}{c}\text { Como essa } \\
\text { resposta } \\
\text { funciona de } \\
\text { forma detalhada }\end{array}$ & $\begin{array}{c}\text { Eficácia e } \\
\text { evidência dos } \\
\text { resultados } \\
\text { abordagem } \\
\text { da }\end{array}$ & $\begin{array}{c}\text { Limitacoes } \\
\text { Fornece } \\
\text { insights }\end{array}$ \\
\hline Novo Coronavírus & $\mathrm{X}$ & $\mathrm{X}$ & $\mathrm{X}$ & $\mathrm{X}$ & $\mathrm{X}$ \\
\hline Folia sustentável & $\mathrm{X}$ & $\mathrm{X}$ & $\mathrm{X}$ & $\mathrm{X}$ & $\mathrm{X}$ \\
\hline Plantadores de árvores & $\mathrm{X}$ & $\mathrm{X}$ & $\mathrm{X}$ & $\mathrm{X}$ & $\mathrm{X}$ \\
\hline $\begin{array}{c}\text { Brasil trata menos da } \\
\text { metade do esgoto que gera }\end{array}$ & $\mathrm{X}$ & $\mathrm{X}$ & & $\mathrm{X}$ \\
\hline
\end{tabular}

Fonte: Solutions Journalism Network ${ }^{3}$.

\section{1. "Пnouo Coronauírus: Cuidados no cotidiano"}

A reportagem, veiculada em 22 de março de 2020, produzida pelo jornalista André Trigueiro e que conta com 24 minutos de duração, aborda o coronavírus e os cuidados necessários para que as pessoas possam se proteger na rua e em casa. São apresentadas questões como: higiene das mãos e objetos, como abrir portas sem tocá-las com as mãos e os cuidados ao chegar e sair de casa. Através da análise da reportagem, é possível concluir que se enquadra no conceito do JS, já que todas as características descritas pela Solutions Journalism Network, podem ser relacionadas com o material analisado.

A característica profundidade da resposta pode ser notada a partir do momento que a especialista especifica todos os cuidados necessários na higienização de mãos e alimentos ao mesmo tempo em que ela e o jornalista executam para proporcionar maior clareza. $\mathrm{O}$ trecho, a partir dos cinco minutos, ajuda na compreensão da característica exposta, além de contar com uma conversa entre os dois, onde o processo de lavagem das mãos é mostrado do início ao fim: “Tirar relógio, pulseira. Deixa eu ver se está lavando certo, lavou a palma, a ponta, costa de mãos, entre dedos, punho. Tem uma coisinha que não foi ainda, o polegar". E ainda, sobre os cuidados em casa, "você pode fazer deste banheiro o primeiro lugar que vai quando chega em casa, nem todo mundo, às vezes tem condição de ter um banheiro que possa dedicar a isso, e o cuidado também, que se você tem uma família, a

3 Tradução livre feita pela autora, retirada do site https://www.solutionsjournalism.org/. Acesso em: 20 Ago. 2020. 
toalha deve ser de uso individual”. Por esta razão, a característica como a resposta funciona de forma detalhada também fica evidenciada.

A reportagem também fornece insights, ao passo que vai apresentando formas de reduzir os riscos de contágio e como podemos ajudar grupos vulneráveis a se protegerem, como no trecho onde dá dicas de ajuda aos idosos: "Se você tem um idoso, eu sou mais nova, eu posso me oferecer pra ir no mercado e comprar alguma coisa pra ele".

A limitação da abordagem se estabelece no fato de que quando foi produzida, vacinas ainda não haviam sido desenvolvidas e, por isso, não existia um fator de proteção totalmente eficaz, o que é deixado bem claro no decorrer da reportagem, mais especificamente, nos 14 minutos de reportagem com a fala da especialista: "A gente não vai conseguir ser imune $100 \%$, isso é importante. Agora, a gente ajuda mantendo a distância, limpando, lembra da maçaneta".

\section{2. "Folia sustentáuel"}

A segunda reportagem, veiculada em 21 de fevereiro de 2020, aborda maneiras sustentáveis de realizar o Carnaval, sem agredir o meio ambiente e sem gerar poluição excessiva. Na edição, são apresentadas formas de diminuir a emissão de poluentes provindos de combustíveis, como produzir glitter e purpurina biodegradáveis e roupas e ornamentos de carnaval duráveis por meio do crochê. Através da análise, "Folia Sustentável" se enquadra na categoria do JS, pois todas as características podem ser percebidas. Uma das mais claras e recorrentes é o fator "fornecer insights", pois são mostradas formas de realizar um evento sem gerar excesso de lixo, como nas partes extraídas a seguir: "A gente produz todos os anos, os coletores que vão estar instalados nos postes para que o folião possa fazer o descarte correto". E sobre a confecção de ornamentos: "Estamos fazendo a partir de duas garrafas pet, estamos desenvolvendo um cocar, que também é ajustável, todo com material reciclado".

A resposta ao problema é detalhada pois mostra como novas ações impactam positivamente, explicando como é possível realizar os procedimentos, enquadrando-se também na categoria profundidade da resposta já que não se limita apenas a mostrar, mas explica e apresenta passo a passo como fazer a "solução". Logo no primeiro minuto isso é exposto: "Nosso bloco funciona com $100 \%$ de energia renovável, essa energia vem do folião, então cada uma das bicicletas tem um gerador elétrico que transforma energia 
humana em eletricidade". Em seguida, o exemplo é apresentado na prática. "Cada bicicleta tem um gerador elétrico no cubo. Quando você pedala lá dentro dele você movimenta o ímã que arrasta os elétrons do cobre, esses elétrons são colocados no nosso sistema de retificação e abastecem toda energia elétrica dos amplificadores".

A eficácia dos resultados fica a cargo dos números apresentados em relação à produção e utilização do óleo diesel:

\begin{abstract}
Não usamos nenhum combustível, a não ser energia humana e muito menos bateria do tipo chumbo ácido ou lítio que é pior ainda, para armazenar energia. Aqui é $100 \%$, diferente de muitos blocos de carnaval que usam caminhões, trios elétricos enormes, com grandes amplificadores, que consomem 300, 400 litros de óleo diesel, em uma única tarde de carnaval.
\end{abstract}

Já a limitação é exposta quando os valores para a produção dos materiais, como a purpurina biodegradável, são questionados. Apesar de ser uma solução útil, o alto valor não a torna viável para todos:

E o custo de uma purpurina como essa é mais alto que o da purpurina normal? Com certeza, porque por ser uma coisa feitos artesanalmente e com insumos que são caros, ela tem um custo alto né, bem mais alto que o glitter comum, porque o plástico é um material muito barato.

\title{
3. "Plantadores de Áruores"
}

A reportagem intitulada "Plantadores de Árvores" apresenta histórias e soluções com a temática: como aumentar áreas verdes e se beneficiar com a ação. A primeira solução apresentada é de um produto desenvolvido para proteger as mudas durante o reflorestamento, chamado de nucleário. As funções e como ele funciona são apresentadas de forma detalhada logo ao início da reportagem: "As partes de câmaras de ar que ele tem internamente são inspiradas nas sementes aladas, o nucleário funciona em camadas, no caso aqui a gente as camadas de proteção do solo, para que? Pra gente frear a entrada da água, segurar os nutrientes no solo". Os resultados obtidos também são informados, mostrando a eficácia e evidência dos resultados:

A gente lá no campo, consegue capturar com dois sensores e um datalog, os níveis de umidade do solo. Então a gente consegue ver perfeitamente a diferença de umidade do nucleário pro grupo controle. Então quer dizer, ele está retendo a umidade do solo e fazendo com que essa umidade atraia a biodiversidade e favoreça o crescimento da muda. 
É possível constatar que o produto está sendo utilizado por corporações com projetos de plantio de árvores, porém a tecnologia não está à disposição de todas as pessoas, por estar em fase inicial e requerer algumas modificações ou por outros motivos que não foram informados na reportagem.

Já a segunda história aborda a ação de um morador de São Paulo que começou a plantar árvores em um parque da cidade, uma ação que teve impacto e deu vida ao primeiro Parque Linear da cidade (localizado dentro da área urbana). Porém, o JS diz que a matéria pode apresentar um personagem, mas o foco deve ser a solução. Apesar de mostrar uma solução e fornecer insights sobre a iniciativa, o personagem ganhou mais relevância. A última parte da reportagem trata sobre o reuso da água e o papel do plantio de árvores nas margens de rios. Apesar de estar dividida em três partes, com histórias diferentes e não contendo todas as características em cada uma delas, na totalidade é possível enquadrá-la como uma produção que segue os preceitos do JS.

Profundidade da resposta e como funciona de forma detalhada são as características presentes em todas, assim como fornecer insights. Um exemplo claro de insight é apresentado no momento onde abordam sobre o reuso da água: "Estamos trabalhando o reuso da água cinza, uma água de baixa qualidade que geralmente é jogada fora, em qualquer lugar e que agora passa por um prévio tratamento, de baixo custo e que é direcionada para um sistema agroflorestal".

$\mathrm{Na}$ última parte da reportagem, em que a questão do plantio e reuso da água são expostas, está presente a limitação, é deixado claro que os estudos ainda estão em andamento. "Como essa água vai se comportar né, e como essas plantas vão se comportar com essa água, isso é objeto de estudos que estamos fazendo, enquanto universidade e academia, estudos mais apurados e científicos para trazer essa resposta aos agricultores". Embora o intuito da reportagem seja o de apresentar soluções para o aquecimento global a partir do plantio de novas árvores, um insight muito interessante é apresentado, sobre a reinserção de presidiários à sociedade através do trabalho em projetos que visam aumentar áreas verdes. "Todos que participam do programa acumulam conhecimento em várias áreas [...] Todo processo de revegetação é do conhecimento dessas pessoas. Quer dizer, isso que eles acumulam tem servido para eles se inserirem no mercado de trabalho". 


\title{
4. "Brasil trata menos da metade do esgoto que gera"
}

A última reportagem analisada, de abril de 2018 e com duração de 20 minutos, dá luz a uma problemática importante que se vive no Brasil: a inutilização e falta de tratamento dos esgotos. Também foi dividida em três histórias, ambas com a mesma temática, cada uma mostrando uma solução diferente para o esgoto gerado. Na primeira parte, sobre a transformação do esgoto em adubo, constata-se, a partir dos três minutos, a presença das características profundidade da resposta e como funciona de forma aplicada:

\begin{abstract}
Aqui é propriamente o lodo antes de ser desaguado. O que ocorreu? Ocorreu a transformação, a conversão entre o carbono orgânico que é presente no esgoto por biomassa bacteriana. Basicamente o lodo do esgoto é composto por biomassa bacteriana. Posteriormente, ele será desaguado ou em leitos de secagem ou em centrífugas. Esse processo consiste na adição de cal na proporção de 30 a $50 \%$, onde promove a redução de eventuais patogênicos que possam causar doenças para a população.
\end{abstract}

Apesar do procedimento ser apresentado junto da explicação, a linguagem utilizada é mais técnica, o que pode prejudicar o entendimento do público sobre como reproduzir o exemplo, já que em programas de televisão a linguagem a se utilizar visa o mais simples e coloquial possível para que todos possam compreender.

Logo na sequência, são explicitados os resultados obtidos nas plantações:

\begin{abstract}
Nós estamos aplicando no café e tá vendo um resultado bom. Nós tínhamos uma produtividade de 30 sacas por hectare e aumentamos para 43 sacas por hectare de café [...] Deu mais produtividade, o custo diminuiu com o lodo, exige menos adubação química". E ainda, o relato de um produtor de trigo que também se beneficiou com o produto: Aumentou o lucro, porque a produção aumentou muito, sabe. Eu colhia em média, de 100, 110 sacos nessa área que eu usei o produto. Agora tô colhendo 150, 170 sacos por alqueire.
\end{abstract}

A limitação também aparece, a partir do momento que especialistas explicam que o lodo não pode ser utilizado em algumas culturas: "Pra gente aplicar esse produto primeiro tem que ter um projeto, e não é um projeto simples, é um projeto complexo porque precisa saber da cultura. Tem cultura que não é permitida, a legislação ambiental não permite".

A segunda parte discorre sobre a produção de combustível através do esgoto na cidade de Franca, inspirado no exemplo da Alemanha que já o utiliza para este fim. Apesar de ser uma solução extremamente útil e eficiente, a limitação é grande pois apenas $2 \%$ dos carros são adaptados para o uso do gás natural: "O pequeno número de carros adaptados para o uso de gás como combustível é outro entrave. São apenas $2 \%$ dos 
veículos no Brasil”. A profundidade da resposta e como funciona de forma detalhada são características bem presentes e que tornam a reportagem extremamente completa, já que todo o processo é explicado:

\footnotetext{
Na estação da Sabesp, a parte líquida do esgoto é separada da parte sólida. A água limpa volta para os rios. O lodo que é o sólido vem para esses tanques chamados biodigestores onde fica por até 30 dias para a decomposição. Esse processo gera gases, entre eles, o gás metano com alto poder de combustão [...] Um sistema de filtros separa o metano das outras substâncias geradas no biodigestor.
}

Após a descrição do processo, são apresentados os números que a ação já gera: "Por enquanto, só os carros da Sabesp de Franca serão abastecidos com o biogás do esgoto. A empresa pretende economizar 1500 litros de gasolina por dia.”. E também, aponta uma estimativa do impacto após a tecnologia começar a ser utilizada de forma ampla: "Essa estação de tratamento de esgoto, que atende a 270 mil pessoas, vai produzir biogás já purificado que vai abastecer mais de 200 automóveis e isso pode ser replicado pelo país afora". Além da eficácia e evidência dos resultados da utilização do biogás, o tratamento correto do esgoto trouxe outro resultado positivo e benefícios à cidade: "Em Franca, a taxa de internação por falta de saneamento é baixa: 10/100 mil habitantes". Toda a reportagem é um grande insight, com vários exemplos de usos criativos e inteligentes do esgoto, que traz o questionamento do porquê a tecnologia ainda não é utilizada em larga escala. Através da fala de um dos funcionários da empresa, o insight ganha destaque: "O que nós estamos aqui fazendo de forma pioneira é utilizar esse biogás que em geral é queimado, de uma forma útil, quer dizer, separando os componentes que são nocivos para a combustão com processos químicos, como a filtragem nós conseguimos produzir um produto puro o suficiente para ser utilizado nos veículos".

O terceiro uso do esgoto diz respeito a geração de energia através do tratamento. A tecnologia ainda não é disponibilizada para a população, está em uso apenas na empresa, que já apresenta alguns números, mostrando assim, a eficácia e evidência dos resultados: "A economia de energia elétrica supera um milhão de reais por ano". Indo além dos resultados já alcançados, é apresentada uma estimativa para quando a solução for implementada na cidade: "Quando tiver o motogerador conectado à rede a gente vai gerar 2.8 megawatts que é o equivalente, se eu fosse assim pra quem tá em casa entender, é o equivalente a energia consumida para duas mil casas populares". Outros insights que 
puderam ser percebidos durante a análise da reportagem são sobre como solucionar o problema do mau cheiro do esgoto e contaminação do solo, que afetam inúmeras localidades e que a empresa conseguiu resolver:

\begin{abstract}
A gente não tem mais lodo que não passe por tubulação, então acho que uma grande vantagem é essa. A maioria das estações de tratamento tem o cheiro que incomoda a população. Aqui na nossa empresa não tem. Então o lodo vem da Sanepar até chegar ao nosso tanque de biodigestão, ele vem todo por tubulação. Então a gente não tem mais nenhum problema de contaminação do solo.
\end{abstract}

Com a análise das quatro reportagens finalizadas, foi possível constatar as diferenças que as reportagens de Jornalismo de Solução expressam. É importante destacar que a escolha dos temas representa grande influência na produção das reportagens com estas características, já que não são todos os assuntos que abrem espaço para uma abordagem como a do JS. Grande parte das edições do Cidades e Soluções tratam sobre problemas sanitários e ambientais, sustentabilidade e uso adequado dos recursos naturais, temas que permitem expor soluções e exemplos positivos. São reportagens que levam mais do que o retrato de um problema, mas também soluções eficazes, baseadas em estudos e utilizações que geraram grandes resultados, criando no telespectador uma inspiração para tentar solucionar os mesmos problemas no local onde vive. Em três das quatro edições, são apontadas mais de uma história que, se analisadas individualmente, não se enquadram como JS, mas a totalidade as torna reportagens de Jornalismo de Solução. Ambas trazem problemas expressivos no Brasil, como o esgoto, desmatamento, produção de lixo e o mais recente, o coronavírus.

Entretanto, é importante pontuar aspectos que poderiam facilitar o entendimento e a prática das soluções que apresentadas. Em algumas das edições, é possível perceber o uso de uma linguagem mais técnica durante a explicação dos processos. Muitas vezes, o uso destes termos se faz necessário para uma abordagem completa, porém é preciso pensar formas de democratizar e trazer uma linguagem mais simplificada já que o intuito do JS é que as soluções sejam replicadas. Ainda sobre buscar maneiras de facilitar o acesso, algumas das soluções acabam sendo inviáveis se pensadas em todo o território brasileiro, seja pela falta de investimentos e infraestrutura ou pelo alto custo, apesar dos benefícios a longo prazo. Diferentemente da reportagem "Folia Sustentável”, que traz maneiras simples de reutilizar materiais que seriam descartados, e "Plantadores de Árvores", que em uma das histórias aborda a simples solução de começar a plantar árvores, as demais requerem 
investimentos, estudo e incentivos para serem implementadas e disponibilizadas para todos.

\section{CONSIDERAÇÔES FIחAIS}

O presente estudo sobre Jornalismo de Solução delimitou como objetivo analisar o programa Cidades e Soluções, veiculado pela GloboNews, à luz dos conceitos de JS propostos pela Solutions Journalism Network. Através da análise de conteúdo, o corpus foi estudado com o auxílio de um quadro para a verificação do número de características e, em seguida, com trechos das edições do programa pôde ser realizada a análise qualitativa. Por meio da análise de conteúdo, foi possível concluir que o programa Cidades e Soluções se enquadra como uma produção de Jornalismo de Solução, apresentando nas edições selecionadas, todas as características estabelecidas pela organização de Jornalismo de Solução. Apenas na reportagem sobre o novo coronavírus não foi possível constatar a característica eficácia e evidência dos resultados, mas isso se justifica ao passo que a matéria foi gravada no início da pandemia e ainda não haviam sido produzidas vacinas.

O Jornalismo de Solução vem se mostrando como um tema de grande relevância para o jornalismo atual, constantemente atacado pelo distanciamento com o público e pela veiculação de notícias negativas. Dessa forma, as contribuições aqui apresentadas são de extrema importância pois apresentam o JS e sua forma singular de produzir jornalismo, que além de expor o problema, inclui todo o contexto e as soluções que podem ser reproduzidas. Junto a isso, o JS ainda é um tema pouco pautado em pesquisas científicas, uma das limitações do artigo. Por conseguinte, grande parte da bibliografia foi retirada de artigos on-line e as características utilizadas para a análise foram extraídas do site da Solutions Journalism Network e traduzidas para melhor compreensão do tema. A limitação também se encontra no fato da categoria ainda ser negligenciada no jornalismo brasileiro, sendo vista em poucas iniciativas, como a mais recente do Grupo RBS. A contribuição aqui desenvolvida se mostra promissora pois características mais concretas foram elencadas, uma bibliografia do JS e os antecessores também foram apresentadas.

Estudos futuros sobre como o Jornalismo de Solução aumenta o engajamento e o relacionamento com o público podem ser de grande valia para o jornalismo, bem como, a forma que o JS pode promover mais credibilidade para o jornalismo na atualidade. 


\section{REFERÊกCIAS BIBLIOGRÁFICAS}

CABRAL, Raquel; SALHANI, Jorge. Jornalismo para a paz: conceitos e reflexões.

Revista da Associação Nacional dos Programas de Pós-Graduação em Comunicação -

E-compós, Brasília, v.20, n.3, 2017. Disponível em: https://www.e-compos.org.br/ecompos/article/view/1371/947. Acesso em: 21 set. 2020.

CARDOSO. Z, Anelise. Jornalismo para paz ou para a guerra: o refugiado na cobertura jornalística brasileira. Tese (Doutorado em Comunicação e Informação), Universidade Federal do Rio Grande do Sul, Porto Alegre, 2013. Disponível em: https://lume.ufrgs.br/bitstream/handle/10183/105023/000943240.pdf?sequence=1\&isAllo wed=y. Acesso em: 05 set. 2020.

DE SOUZA, G. Mariana. Jornalismo de Soluções: Um caminho possível. Trabalho de Conclusão de Curso (Graduação em Jornalismo). Universidade Federal do Rio Grande do Sul, Porto Alegre, 2017. Disponível em: https://lume.ufrgs.br/handle/10183/177692. Acesso em: 22 abr. 2020.

HERSCOVITZ, G. Heloiza. “Análise de Conteúdo em Jornalismo”. In: LAGO, Claudia; BENETTI, Marcia. Metodologia da Pesquisa em Jornalismo. Coleção Fazer Jornalismo. Editora Vozes. 2010.

LIMA. A. A, Marcus; MOTA. M, Flávia. Jornalismo Cívico como alternativa e ferramenta para uma prática mais social da comunicação. Revista Pauta Geral - Estudos em Jornalismo, Ponta Grossa, v. 1, n.1, p. 22-39, 2014. Disponível em: http://www.bibliotekevirtual.org/index.php/2013-02-07-03-02-35/2013-02-07-03-0311/1230-pautageral/v01n02/13031-jornalismo-civico-como-alternativa-e-ferramenta-parauma-pratica-mais-social-da-comunicacao.html. Acesso em: 05 set. 2020.

LOOSE, B. Eloisa. "Jornalismo de Soluções e mudanças climáticas: Estudo sobre a cobertura da mitigação no site brasileiro G1”. In: FERNÁNDEZ-REYES, Rogelio; RODRIGO-CANO, Daniel (Orgs.). La Comunicación de la mitigación ante la 
emergencia climática. 1.ed. Colección Comunicación Y Pensamiento. Editora Egregius, 2019. Disponível em:

https://idus.us.es/bitstream/handle/11441/91468/cap.\%204.pdf?sequence=1\&isAllowed=y. Acesso em: 22 abr. 2020.

SILVA, R. D. G. da. O papel social do jornalismo cívico e a interação midiática entre o jornalista e as minorias sociais. Revista de C. Humanas, Minas Gerais, v.12, n.1, jan./jun. 2012. Disponível em: http://www.cch.ufv.br/revista/pdfs/artigo5vol12-1.pdf. Acesso em: 02 de out. 2020.

SOLUTIONS JOURNALISM NETWORK. Página inicial. 2020. Disponível em: https://www.solutionsjournalism.org/. Acesso em: 20 ago. 2020.

SOUZA, R. B. Rafael. A dialética da crise do jornalismo: o sociometabolismo do capital e seus limites estruturais. Intercom - RBCC, São Paulo, v. 41, n. 2, p. 55-69, mai./ago. 2018. Disponível em: https://www.scielo.br/scielo.php?script=sci_arttext\&pid=S180958442018000200055\&lng=pt\&tlng=pt\#fn01. Acesso em: 29 mar. 2020.

WENZEL, Andrea; GERSON, Daniela; MORENO, Evelyn. Engaging Communities Through Solutions Journalism. 2016. Disponível em:

https://www.cjr.org/tow_center_reports/engaging_communities_through_solutions_journal ism.php. Acesso em: 10 set. 2020. 